\title{
Dinacharya (Daily regimen): A Syndromic Approach to Prevention of Non Communicable Diseases
}

\author{
Dr. Ramesh Kant Dubey* \\ Lecturer, Deptt. of Swasthavritta, Govt. P.G. Ayurvedic College \& Hospital, S.S.University, Varanasi. \\ *Corresponding Author: Dr. Ramesh Kant Dubey, Lecturer, Deptt. of Swasthavritta, Govt. P.G. Ayurvedic \\ College \& Hospital, S.S.University, Varanasi.
}

\begin{abstract}
:
Purpose

Dinacharya which consists of group of measures for prevention of various diseases as a syndromic approach is a unique concept of Ayurveda where a single measure like exercise is able to prevent multiple diseases such as diabetes mellitus, obesity, and coronary artery disease and so on. No such concept appears to be present in contemporary medical practices although a lot of importance has been given to dietary regulations and exercise in prevention and management of non communicable diseases such as ischemic heart disease and diabetes mellitus. The present study had been undertaken to collect modern scientific evidences in support of Dinacharya (daily regimen) mentioned in ancient Ayurvedic texts and its role in preventing non communicable diseases.
\end{abstract}

\section{Methods}

Details of Dinacharya available in Ayurvedic classical texts were examined and related modern knowledge on the subject was explored in various books and internet search engines like PubMed.The information gathered from both the streams were correlated and critically analyzed.

\section{Discussion}

Dinacharya includes dietary and lifestyle measures to be followed per day for a healthy and disease free life. In Ayurveda, special attention has been given on time of awakening, exercise, massage, regular bath and healthy lifestyle related advices along with Sadvritta i.e. beneficial social and behavioral practices. It is a collection of natural lifestyle in accordance with circadian rhythm. The analysis of knowledge obtained from ancient as well as modern books and internet provided a strong support to different steps of Dinacharya. Its various components not only help in preserving and promoting physical and mental health but also help in social and spiritual well being thereby preventing the person from various diseases for example regular exercise prevents from obesity and diabetes mellitus.

\section{Conclusion}

Dinacharya (daily regimen) developed by ancient Ayurvedic scientists is a method of primordial prevention and also an adjuvant to primary and secondary prevention of non communicable diseases.

Keywords: Daily Regimen, on communicable diseases, Dinacharya

\section{INTRODUCTION}

Dosha (functional constituents ie Vata, Pitta, Kapha), Dhatu (structural constituents ie Rasa, Rakta, Mamsa, Meda, Asthti, Majja and Shukra) and Mala ( excretory products ie Mutra, Purisha and Sweda ) are principle constituents of the body. Balance or imbalance of these constituents is responsible for health or disease respectively. Deviation of body constituents from their normal levels due to various causative factors leads diseases and the treatment aims at achieving natural values of body constituents by using Ahar (diet), Vihar (life style) and Aushadh (Medicine). ${ }^{1}$ Variations occur in levels of Doshas in relation to age, day, night, and food intake. ${ }^{2}$ Seasons also affect Doshas. ${ }^{3}$ In order to normalize diurnal variations, Diancharya (daily regimen) has been advocated while Rituchatya (seasonal regimen) helps to combat seasonal effects. Dinacharya consists of dietary and lifestyle measures to be followed per day for a healthy and disease free life. 
Non communicable diseases (NCDs), also known as chronic diseases, result from a combination of genetic, physiological, environmental and behaviors factors and usually tend to be of long duration. ${ }^{4}$. Advances in medical science has been capable of preventing communicable diseases but the changes in lifestyle and dietary habits has lead to the danger of epidemic of non communicable diseases. Modern medicine alone has been unable to prevent them .So the World is looking towards the alternatives. Recent researches have supported the effective role of Ayurveda in these diseases.

Non -communicable diseases (NCDs) consist of cardiovascular, renal, nervous and mental diseases, musculoskeletal conditions such as arthritis, chronic non -specific respiratory diseases (eg COPD, asthma), blindness, cancer, diabetes , obesity and various degenerative diseases. ${ }^{5}$.About 41 million people each year, equivalent to $71 \%$ of all deaths globally are killed by NCDs. Each year, 15 million people die from a NCD between the ages of 30 and 69 years; over $85 \%$ of which are from low- and middle-income countries. Cardiovascular diseases are cause of the most NCD deaths, or 17.9 million people annually, followed by cancers ( 9.0 million), respiratory diseases (3.9million), and diabetes (1.6 million). In fact, these 4 groups of diseases cause over $80 \%$ of all premature NCD deaths. ${ }^{6}$ Out of the 57 million global death in 2008 , it is found that 36 million or 63 percent were due to NCDs. 47.9 percent deaths were due to cardiovascular diseases, 21 percent due to cancer, 11.72 due to chronic respiratory diseases, 6.1 percent due to digestive diseases,3.5 percent diabetes and 9.78 percent due to other NCDs. Death due to NCDs is estimated to rise to 52 million by $2030 .^{7}$ The common Non-communicable disease risk factors are cigarette smoking, alcohol abuse, inability to obtain preventive heath services, life style changes, environmental risk factors and stress. NCDs are multifactorial in causation so their prevention demands a complex mix of interventions. As risk factors are being identified, health promotion activities aimed at primary prevention are being applied to control NCDs. ${ }^{8}$ Detection, screening and treatment of NCDs, as well as palliative care, are key components of the response to NCDs. ${ }^{9}$

Importance of lifestyle in maintenance of health and generation of diseases is well recognized in Ayurveda. Role of chemical agents in managing diseases is only a partial attempt towards the maintenance of homeostasis in the body. Dinacharya is a unique concept of Ayurveda which consists of group of measures directed towards prevention of various diseases as a syndromic approach.

\section{Objectives}

1. To study Dinacharya in Ayurveda.

2. . To study Dinacharya in the light of modern knowledge on the subject and its role in non communicable disease.

\section{MAterials AND MethodS}

Details of Dinacharya available in Ayurvedic classical texts were examined and related modern knowledge on the subject was explored in various books and internet search engines like Google, Google Scholar, PubMed .The term 'Dinacharya ' was searched in Google and pub med which revealed about 152 related articles and only five were relevant to the topic. The information gathered from both the streams and internet were carefully examined, correlated and critically analyzed.

\section{Concept of Dinacharya -as per Ayurvedic Classical texts}

Dinacharya is a unique concept of Ayurveda which consists of group of Daily Life' routine instructions which if followed as life style shall prevent life style related ailments and it corresponds to the daily routine activities that every person needs to carryout in order to maintain a good and healthy life. Dinacharya may be considered as a syndromic approach to prevention as well as treatment of various diseases especially lifestyle and chronic diseases. All the activities of living being in the World start with arise of Sun and completed with Sun set .So maintaining daily activities with the beginning of the day and gradually going to the rest at the end of the day is definitely in accordance with the nature .

Different activities included in Dinacharya as available in different classical texts are mentioned in Table No. 1.

Table1. Dinacharya (Daily Regimen) ${ }^{10,11,12}$

\begin{tabular}{|l|l|l|}
\hline S.No. & Dinacharya Steps & Description \\
\hline 1. & Arising in Brahma Muhurta & $\begin{array}{c}\text { First step is awakening in the early hours of the day. } \\
\text { Brahma Muhurta is the fourteenth Muhurta of night .It is } \\
\text { appropriate for awakening.Due to variation in the time of } \\
\text { Sun rise ,the time of Brahma Muhurta varies from region to }\end{array}$ \\
\hline
\end{tabular}


Dinacharya (Daily regimen): A Syndromic Approach to Prevention of Non Communicable Diseases

\begin{tabular}{|c|c|c|}
\hline & & $\begin{array}{l}\text { region .It is about two Muhurta ( ie } 96 \text { minutes or } 1.5 \text { hours } \\
\text { ) before Sun rise }\end{array}$ \\
\hline 2. & Usha Jalapana & Drinking water in the morning \\
\hline 3. & Sharirachinta & To think about the body \\
\hline 4. & Malatyaga & Excretory procedures \\
\hline 5. & Mukha prakshalan & Mouth wash \\
\hline 6. & Dantadhavana & Cleaning Teeth \\
\hline 7. & Jihvanirlekhanavidhi & Tongue Cleaning \\
\hline 8. & Anjana & Medicines applied in eyes \\
\hline 9. & Pratimarsha Nasya & Putting oil/medicated in nostrils \\
\hline 10. & Gandusha and Kavala & Gargling with oil and medicated decoctions \\
\hline 11. & Tambulasevana & Chewing betel leaves along with other herbal drugs \\
\hline 12. & Dhoomapana & Medicated smoke or fume inhalation \\
\hline 13. & Abhyanga & Massage \\
\hline 14. & Udvartana & A variet of massage with dry medicinal powders \\
\hline 15. & Utsadana & A specific massage with herbs and oil \\
\hline 16. & Vyayama & Physical Exercise \\
\hline 17. & Chankramana & $\begin{array}{l}\text { Minimum exercise causing no discomfort to body.It } \\
\text { increases lifespan,strength,intelligence, digestive power } \\
\text { and perceptive power of sense organs. }\end{array}$ \\
\hline 18. & Snana & Bath \\
\hline 19. & Anulepana & $\begin{array}{l}\text { Applying powder of Santalam album and other herbs after } \\
\text { bath }\end{array}$ \\
\hline 20. & Vastra dharana & Clothing \\
\hline 21. & Danda dharana & Keeping stick while walking outdoor \\
\hline 22. & Padatra dharana & Wearing shoes etc \\
\hline 23. & Chatra dharana & Using umbrella \\
\hline 24. & Ushnisha dharana & Covering head with cloth specifically \\
\hline 25. & Ratnabharana dharana & Wearing ornaments \\
\hline 26. & Madhyahna charya & Afternoon regimen \\
\hline 27. & Sandhya charya & Evenig regimen \\
\hline 28. & Rathri bhojana vidhi & Method of taking dinner \\
\hline 29. & Shayanavidhi & Sleeping method \\
\hline
\end{tabular}

\section{Non Communicable diseases and Lifestyle}

Lifestyle has important role in causation and prevention of Non communicable diseases (NCDs).These diseases have multiple causative factors which rarely have one to one causative effect. Many causative factors have associative effect and their presence does not necessarily cause the disease. Besides these, non -communicable diseases (NCDs) also have gradual onset, long natural history, and require prolonged treatment along with multi disciplinary approach in prevention and control. All NCDs have some common risk factors which can be categorized as modifiable and non modifiable. Modifiable risk factors are smoking, alcohol, high blood pressure, overweight/obesity, insufficient physical activity, Low intake of fruits and vegetables and alcohol .Non-modifiable risk factors are age, sex, genetic susceptibility and family history. ${ }^{13}$

NCDs are prevalent in the people of all age groups, regions and countries. 15 million of all deaths due to NCDs occur between the ages of 30 and 69 years. and over $85 \%$ of these deaths are estimated to occur in low- and middle-income countries.Various researches have shown that tobacco use, physical inactivity, unhealthy diet and the harmful use of alcohol, all increase the risk of NCDs. Tobacco accounts for over 7.2 million deaths every year. Excess salt/sodium Intake leads to 4.1 million annual deaths .More than half of the 3.3 million annual deaths occurring due to alcohol use are from NCDs, including cancer while insufficient physical activity leads to 1.6 million deaths annually.There are four metabolic changes ie increased blood pressure ,overweight/obesity ,hyperglycemia and hyperlipidemia that increase the risk of NCDs.

In order to reduce the harmful effects of NCDs on individuals and society, a comprehensive approach is required from all sectors, including health, finance, transport, education, agriculture, planning and 
others, to collaborate to reduce the risks associated with NCDs, and promote interventions to prevent and control them. ${ }^{14}$

It is being recognized that non communicable diseases can be prevented and managed by an integrated approach targeting the multiple risk factors like changing lifestyle to include sufficient physical activity can reduce the multiple diseases like Diabetes mellitus ,obesity, hypertension, coronary heart disease and so on.

\section{DISCUSSION}

Nija (Endogenous),Agantuja (Exogenous) and Manas (mental) are the three types of diseases described in Ayurveda. Imbalance of Doshas contribute to endogenous diseases and exogenous diseases are caused by external factors such as Visha (poison), Vayu (air), Agni (fire), Samprahar (trauma) etc. while Manas (mental ) illness results from failure to obtain favorable substances and obtaining substances which are unfavorable. Non communicable diseases can be included in Nija (Endogenous) while communicable diseases are considered under Agantuja (Exogenous). ${ }^{15}$

For emergence of diseases etiological factors are essential and the best way of their prevention is removal or avoidance of etiological factors. Non communicable diseases have multiple risk factors. Dinacharya is a unique concept of Ayurveda which consists of group of measures directed towards prevention of various diseases as a syndromic approach by avoiding multiple risk factors in a routine practice and it may be considered as a primordial preventive measure especially for non communicable diseases. Dinacharya includes various beneficial measures related to diet and lifestyle which needs to be followed day to day beginning from the day till the person goes to sleep. ${ }^{16}$. Although all the components described under Dinacharya are related to the maintenance of health and management of diseased but some components like arising in Brahmamurta (about one and half hour before sun rise),Abhyanga(massage),Vyayama (exercise), Snana ( Bathing),Ahara (diet).Nidra(sleep) and Sadvritta (beneficial social and behavioral practices) are highly relevant in prevention and management of NCDs. ${ }^{17}$ Arising in Brahma Muhurta and going to sleep at appropriate time in the night helps to maintain body processes in synchronization with circadian rhythm. Circadian rhythms are variations in physiology and behavior with a cycle length close to 24 hours even in the absence of periodic environmental stimuli. Circadian system must be reset on a daily basis in order to remain in synchrony with external environmental time. This process of entrainment is achieved through regular exposure to light and darkness. Thus , maintaining routine activities i.e. Dinacharya is an important measure for maintaining health. ${ }^{18}$

The timing of the most of the biological proceses in the body are regulated by a master clock in the brain.Regional clocks have also been reported in the liver, pancreas and other parts of the. Routinely eating or sleeping at the wrong times may throw these peripheral clocks out of sync with the master clock in the brain. These chronobiological disruptions predispose individuals to the development of obesity, diabetes, depression and other disorders. Resynchronizing the body's many clocks may, in the coming years, help to restore health and proper functioning. This fact strongly supports the ancient Ayurvedic view of arising in the Brahma Muhurta ans sleeping at appropriate time in the night regularly. ${ }^{19}$

In Ayurveda, Abhyangha (massage) has been described to delay aging ,curea tiredness and Vata disorders and produces good sleep and lustrous skin. ${ }^{20}$ In massage therapy there is physical manipulation of muscle and lumber tissue at the site of injury, stiffness, or soreness for the purpose of reducing pain and promoting recovery. ${ }^{21}$ Massage can stimulate parasympathetic activity by reducing heart rate and blood pressure, increasing relaxation substances such as endorphins and increasing cardiac parasympathetic activity and improving measures of relaxation.$^{22}$

Vyayama (exercise) provide stability, increases work ability and endurance ,alleviates Kapha and increases Agni (digestive power). ${ }^{23}$ Maintaining fitness by using judicious regimens of exercise and weight control, have the additional benefit of prolonged life. Especially between the ages of 50 and 70, mortality have been found to be three times less in the most fit people than in the least fit. It is due to reduced cardiovascular disease resulting from maintenance of lower blood pressure and reduced blood cholesterol and low-density lipoprotein along with increased high-density lipoprotein. ${ }^{24}$ Food taken in 
suitable quantity prolongs life and does not aggrevate Doshas and it is easily digested. ${ }^{25}$ Modern medical science also advocate the intake of in proper quantity as well as having balalced amount of various components.

Happiness ,misery ,emaciation ,strength ,sterility, knowledge etc dependent on proper sleep. ${ }^{26}$ Sleep is a naturally occurring state in which, most of the body's systems are in an anabolic state and help to restore the immune, nervous, skeletal, and muscular system. It plays a large role in the function of the endocrine and immune systems. The internal circadian clock regulates sleep by promoting it daily at night. ${ }^{27}$

\section{CONCLUSION}

Dinacharya (daily regimen) developed by ancient Ayurvedic scientists is a method of primordial prevention and also an adjuvant to primary and secondary prevention of non communicable diseases. Ayurveda is a holistic system of health care which primarily focuses on prevention of diseases and promotion of health. The endogenous and exogenous imbalances are responsible for the causation of diseases. Ayurveda provides primordial, primary, secondary as well as tertiary measures for prevention of various diseases in the form of Swasthavritta which includes collection of different routines of the daily life such as Dinacharya (day regime), Ratricharya (night regime), Ritucharya (seasonal regime), Sadvritta (good Conduct),Achara Rasayana (promotive ethical practices ) along with detailed treatment methods for the diseases. Ayurvedic methods of prevention especially Dinacharya is useful in primordial prevention of chronic and lifestyle related diseases.

\section{REFERENCES}

[1] Dubey Sushil Kumar and Dubey Ramesh Kant, The Concept of Langhana in Ayurveda with special reference to Autophagy), Journal of Emerging Technologies and Innovative Research (JETIR) www.jetir.orgSeptember 2018, Volume 5, Issue 9,PP 524-526

[2] Ashtanga Hridaya of Vagbhata with commentaries Sarvangasundra of Arundatta and Ayurveda Rasayana of Hemadri, Chowkhamba Prakashan, Varanasi, 1997. Sutra Sthana 1/7.

[3] Ashtanga Hridaya of Vagbhata with commentaries Sarvangasundra of Arundatta and Ayurveda Rasayana of Hemadri, Chowkhamba Prakashan, Varanasi, 1997. Sutra Sthana 1/19.

[4] http://www.who.int/en/news-room/fact-sheets/detail/noncommunicable-diseases.

[5] Park.K Park's Text Book of Preventive and Social Medicine by K.Park; Banarsi Das Bhawan Publishers, Press Nagar, Jabalpur, M.P, 15th edition 2007.PP 363

[6] http://www.who.int/en/news-room/fact-sheets/detail/noncommunicable-diseases

[7] Park.K Park's Text Book of Preventive and Social Medicine by K.Park; Banarsi Das Bhawan Publishers, Press Nagar, Jabalpur, M.P, 15th edition 2007.PP 362

[8] Park.K Park's Text Book of Preventive and Social Medicine by K.Park; Banarsi Das Bhawan Publishers, Press Nagar, Jabalpur, M.P, 15th edition 2007.PP 363

[9] http://www.who.int/en/news-room/fact-sheets/detail/noncommunicable-diseases

[10] Sharma R.K. \& Dash Bhagawan, Eng. Translation on Charaka Samhita, Chowkhambha Sanskrit Series Office, Varanasi, 2009.Sutra Sthan Chapter 2.

[11] Ashtanga Hridaya of Vagbhata with commentaries Sarvangasundra of Arundatta and Ayurveda Rasayana of Hemadri, Chowkhamba Prakashan, Varanasi, 1997. Sutra Sthana Chapter 2.

[12] Bhava Prakash of Shri Bhava Mishra with Hindi Commentary by Pt. Shri Brahmasankara Mishra, Chaukhambha Sanskrit Sansthan, 4th Edition, 1997. Poorva Khanda Chapter 5.

[13] Suryakantha AH ,Community medicine with recent Advances, J P Brothers Medical Publishers (P) Limited , 2nd edition 2010 .PP 503

[14] http://www.who.int/en/news-room/fact-sheets/detail/noncommunicable-diseases

[15] Sharma R.K. \& Dash Bhagawan, Eng. Translation on Charaka Samhita, Chowkhambha Sanskrit Series Office, Varanasi, 2009.Sutra Sthan Chapter 11/45.

[16] Ashtanga Hridaya of Vagbhata with commentaries Sarvangasundra of Arundatta and Ayurveda Rasayana of Hemadri, Chowkhamba Prakashan, Varanasi, 1997. Sutra Sthana Chapter 2/2.

[17] Sharma R.K. \& Dash Bhagawan, Eng. Translation on Charaka Samhita, Chowkhambha Sanskrit Series Office, Varanasi, 2009.Sutra Sthan Chapter 5/15-104.

[18] Jeanne F. Duffy and Charles A. Czeisler, Effect of light on Human Circadian Physiology,Sleep Med Clin. 2009June;4(2):165-177. doi:10.1016/j.jsmc.2009.01.004. 
[19] Keith C. Summa \& Fred W. Turek, Scientific American 312, 50 - 55 (2015) Published online: 20 January 2015 | doi:10.1038/scientificamerican0215-50)

[20] Ashtanga Hridaya of Vagbhata with commentaries Sarvangasundra of Arundatta and Ayurveda Rasayana of Hemadri, Chowkhamba Prakashan, Varanasi, 1997. Sutra Sthana Chapter 2/7.

[21] Cherkin et al, 2003; Barnes et al, 2008. (http://physiumsystem.com/wpcontent/uploads/2013/07/Mechanisms-of-Action-of-Therapeutical-Massage.pdf downloaded on 10 Oct. 2018)

[22] http://physiumsystem.com/wp-content/uploads/2013/07/Mechanisms-of-Action-of-TherapeuticalMassage.pdf downloaded on 10 Oct. 2018

[23] Sharma R.K. \& Dash Bhagawan, Eng. Translation on Charaka Samhita, Chowkhambha Sanskrit Series Office, Varanasi, 2009.Sutra Sthan Chapter 7/32.

[24] Hall, J. E. 1. (2006). Guyton and Hall textbook of medical physiology (11th edition.). Philadelphia, PA: Elsevier. MLA Citation. Hall, John E. 1946-. PP 1066

[25] Sharma R.K. \& Dash Bhagawan, Eng. Translation on Charaka Samhita, Chowkhambha Sanskrit Series Office, Varanasi, 2009 Viman Sthan Chapter 1/24/3.

[26] Sharma R.K. \& Dash Bhagawan, Eng. Translation on Charaka Samhita, Chowkhambha Sanskrit Series Office, Varanasi, 2009.Sutra Sthan Chapter 21/36-38.

[27] https://en.wikipedia.org/wiki/Sleep\#Awakening downloaded on 10 Oct 2018.

Citation: Dr. Ramesh Kant Dubey, (2020). Dinacharya (Daily regimen): A Syndromic Approach to Prevention of Non Communicable Diseases. International Journal of Medicinal Plants and Natural Products (IJMPNP), 6(2), pp.1-6. http://dx.doi.org/10.20431 /2454-7999.0602001

Copyright: (C) 2020 Authors, this is an open-access article distributed under the terms of the Creative Commons Attribution License, which permits unrestricted use, distribution, and reproduction in any medium, provided the original author and source are credited. 